\title{
NURSES' SATISFACTION WITH THE USE OF COMMUNICATION CHANNELS BY THEIR MANAGERS IN CROATIA AND SLOVENIA
}

\author{
Jasmina Starc* \\ Marijana Neuberg** \\ Karmen Erjavec ${ }^{* * *}$
}

Received: 13. 2. 2017

Preliminary communication

Accepted: 30. 11. 2019

UDC: 61:005.95/.96

DOI: https://doi.org/10.30924/mjcmi.24.2.6

\begin{abstract}
Previous studies rather neglected the issue of how nurses are satisfied with the usage of communication channels by their managers. This paper aims to discover how nurses in Croatia and Slovenia are satisfied with their managers' usage of communication channels, and also how this satisfaction is associated with the employee-organisation relationship. A selfadministrated electronic questionnaire was conducted with 272 nurses in Croatia and Slovenia. The study results show that top nurse managers most commonly use mediated communication channels, while middle and executive nurse managers use more interpersonal communication channels. Employees are most satisfied when top nurse managers use emails, middle nurse managers face-to-face communication, emails and phone calls, and executive nurse managers face-to-face communication, emails, phone calls, instant messaging and internal social networks to communicate with them. Younger employees are significantly more satisfied with nurse managers' use of new communication and information
\end{abstract}

technologies. The study also shows that satisfaction with interpersonal communication used by the executive nurse managers is positively associated with employee-organization relationships and satisfaction with middle and top managers' utilization of email in that relationship.

Keywords: communication management, communication channels, employee-organisation relationships.

\section{INTRODUCTION}

In Croatia and Slovenia, and more broadly in the developed world, health care industry is constantly advancing, due to many new challenges it faces, such as aging populations, a shift from acute illnesses to chronic conditions, shorter hospitalizations, increased complexity in clinical nursing practice and higher patients' expectations

\footnotetext{
* Jasmina Starc, University of Novo mesto Faculty of Business and Management Sciences and University of Novo mesto Faculty of Health Sciences, Na Loko 2, 8000 Novo mesto, Slovenia, Phone: + 3867393 00, E-mail: jasmina.starc@guest.arnes.si

** Marijana Neuberg, University North, University Center Varaždin, Department of Biomedical Sciences, 104. brigade 3, 42000 Varaždin, Croatia, Phone: +385 98/287-370, E-mail: marijana.neuberg@unin.hr

*** Karmen Erjavec, University of Novo mesto, Faculty of Economics and Informatics, Na Loko 2, 8000 Novo mesto, Slovenia, Phone: + 386739300 25, E-mail: karmen.erjavec1@guest.arnes.si
} 
(Zavrl Džananović, 2010; Fernandes, 2013; Prosser and Olson, 2013; Rigolosi, 2013; Kern, 2014). Therefore, the health organizations are undergoing severe changes. Through a systematic review of 37 studies, Lega et al. (2013) found out that nurse managers' knowledge and skills are essential for improving the performance of health organizations, which are providing a significant number of jobs and critical services for citizens. One of the main challenges of present-day nurse managers is how to effectively communicate with employees to achieve informed nurses, who are also generally satisfied employees (Baskin et al., 1997).

It is widely held that communication is the lifeblood of every organization. "Internal communication underpins effectiveness since it contributes to positive internal relationships by enabling communication between managers and employees" (Welch, 2012, p. 246). Having an internal communication that is satisfactory is imperative to productivity, task performance, job satisfaction, commitment and morale (Bharadwaj, 2014; Holmin and Safarova, 2015). Recent studies support McLuhan's notion (1964) that "medium is the message inside organisation (White et al., 2010) as internal communication channels play a symbolic as well as practical role" (Welch, 2012, p. 248). Employees prefer different communication channels from different management levels (Welch, 2012; Men, 2014a, 2014b; Men and Hung-Baesecke, 2015; Erjavec et al., 2018). The advanced information and communication technology introduced new channels of communication and changed the communication environment of organizations (Men and Hung-Baesecke, 2015). Nowadays, managers possess "a wide array of tools to communicate with employees, ranging from traditional channels, such as print media (e.g. newsletters, magazines, and posters), face-to-face communication, emails, and phone calls, to web-based platforms such as intranet, instant messengers, and social networking sites" (Men and HungBaesecke, 2015, pp. 248-249). However, many studies across the globe indicate that there is a communication gap as most nurses complain of not having access to most information issued by their nurse managers (Holá, 2012; Rogers, 2012; Kugović, 2013; Kwateng et al., 2014). As nurse managers at different management levels fulfil different management functions and use different communication channels (Li-Min et al., 2007), the question then arises as to how employees are satisfied with the use of communication channels by their nurse managers.

Despite the growing professional interest and literature on the management communication, there is a lack of studies on employees' satisfaction with the utilisation of communication channels by their managers working at different management levels, especially the lack of studies on the use of communication channels by nurse managers. Therefore, this study aims to fill the research gap by investigating how nurses in Croatia and Slovenia are satisfied with communication channels utilised by their nurse managers at different management levels, and how their satisfaction is associated with the relationship between employees and the organisation.

\section{THEORETICAL BACKGROUND}

\subsection{Communication channels of nurse managers}

Scholars in management and communication fields agree that communication is 
a vital aspect for organizations and that information "may be understood differently depending on the channel through which it is delivered" (Byrne and LeMay, 2006 in Erjavec et al., 2018, p. 559). The challenge for management is to determine what to communicate, when, with whom and most importantly which channel is most convenient for communication (Kwateng et al., 2014; Welch, 2012). The efficiency of organisational communication is usually defined by the managers' usage of communication channels and the method of selection. The channels used shape key aspects of communication and affect the interpretation of the messages (Meyrowitz, 1998).

This study is based on media richness theory, which argues that more complex matters should be delivered through a richer communication channel (e.g. face-to-face) since it is able to convey more information, while more routine matters should use a leaner channel (e.g., printed reports) (Daft and Lengel, 1984). Appropriate communication channel must be selected with regard to the complexity of the message in order to transfer the message successfully. The channel chosen to transmit a message will have a degree of richness which affects the perception of the communication and, therefore, be more or less appropriate in order to convey a certain message (Daft and Lengel, 1984). In her qualitative study, Welch (2012) identified that "preference hierarchy emerged starting with electronic methods; followed by blended methods (electronic and print); and lastly, print internal communication formats" (p. 253). The analys, is based on 407 employees of corporations in China, was conducted by Men and Hung-Baesecke (2015) who found out that face-to-face interactions and social media are channels most employees prefer while communicating with managers.

Table 1. Levels of nurse management*

\begin{tabular}{|c|c|c|c|}
\hline $\begin{array}{l}\text { Management } \\
\text { levels/ } \\
\text { Roles and } \\
\text { activities }\end{array}$ & $\begin{array}{l}\text { Top level } \\
\text { Chief nurse } \\
\text { Chief Nursing Officer }\end{array}$ & $\begin{array}{l}\text { Middle level } \\
\text { Unit supervisor } \\
\text { Department head }\end{array}$ & $\begin{array}{l}\text { Lower/First level } \\
\text { Charge leader } \\
\text { Team leader } \\
\text { Primary nurse }\end{array}$ \\
\hline $\begin{array}{l}\text { Scope of } \\
\text { responsibility }\end{array}$ & $\begin{array}{l}\text { "Look at organisation } \\
\text { as whole, coordinating } \\
\text { internal and external } \\
\text { influences, and } \\
\text { make decisions with } \\
\text { few guidelines or } \\
\text { structures" }\end{array}$ & $\begin{array}{l}\text { "Coordinate the efforts } \\
\text { of lower level of the } \\
\text { hierarchy and are the } \\
\text { conduit between lower and } \\
\text { top-level; Integrating unit- } \\
\text { level day-today needs with } \\
\text { organisational needs" }\end{array}$ & $\begin{array}{l}\text { "Focus primarily on } \\
\text { day-to-day needs at } \\
\text { unit level" }\end{array}$ \\
\hline $\begin{array}{l}\text { Primary } \\
\text { planning focus }\end{array}$ & "Strategic planning" & $\begin{array}{l}\text { "Combination of long-and } \\
\text { short-range planning" }\end{array}$ & $\begin{array}{l}\text { "Short-range, } \\
\text { operational planning" }\end{array}$ \\
\hline $\begin{array}{l}\text { Communication } \\
\text { flow }\end{array}$ & $\begin{array}{l}\text { "Top-down but } \\
\text { receives subordinate } \\
\text { feedback both directly } \\
\text { and via middle-levels } \\
\text { managers" }\end{array}$ & $\begin{array}{l}\text { "Upward and downward } \\
\text { with great centrality" }\end{array}$ & $\begin{array}{l}\text { "More often upward; } \\
\text { generally relies } \\
\text { on middle levels } \\
\text { managers to transmit } \\
\text { communication to top- } \\
\text { levels managers" }\end{array}$ \\
\hline
\end{tabular}

*Adopted from Li-Min et al., 2007; Martinez, 2015, pp. 73-75. 
Manager's level in the organization is characterized by varying degrees of rigor and scope (Li-Min et al., 2007) (Table 1). In Croatia and Slovenia, head nurses are the carriers of top management. Their primary mission is to present nursing care in the healthcare organization, formulate its policy, as well as develop and coordinate research. Top management assigns middle management or the department head and defines her/ his duties and responsibilities to organize, direct, coordinate and supervise the work of nursing care in healthcare organizations at the intermediate level. Middle management "coordinates the efforts of lower levels of the hierarchy and are the conduit between lower and top-level" (Martinez, 2015, p.73). Lower executive management represent one or two lower levels that are above the operational level. Their work relates directly to the implementation of operational management tasks. They are responsible for the provision of services and representing the relationship between the performers and the rest of management. In addition, they coordinate work of their colleagues and try to solve problems promptly. This front-line management is mainly carried out at the operational level, represented by a unit and a team of nurses, who lead other nurses and are responsible for health care (Lorber, 2015; Matić et al., 2014; Starc in Erjavec, 2017). Since no study has examined whether nurses are satisfied with the communication channels used by nurse managers who are working at different levels, the following questions should be addressed:

RQ1: What communication channels do nurse managers at different management levels in Croatia and Slovenia most frequently use to communicate with employees?

RQ2: How are nurses in Croatia and Slovenia satisfied with the usage of managers' communication channels with regards to country, age, gender, education level and sector?

The study anticipates differences in the employees' satisfaction concerning the nurse managers' application of communication channels:

H1: There are differences in the nurses' satisfaction with the application of communication channels by nurse managers working at different management levels with regard to country, gender, age, level of education and sector.

H2: There are differences in the nurses' satisfaction with the usage of different communication channels by nurse managers working at different management levels.

\subsection{Communication channels and employee-organisation relationships}

The relationship management literature is predominately based on Hon and Gruning's (1999) approach, by which the employee-organisation relationship consists of multidimensional outcomes, such as trust, control mutuality, satisfaction, and commitment. Previous studies showed that "if members of an employee public have experienced good quality long-term relationships with their employer organization, they are likely to consider organisational problems as their own" (Kim and Rhee, 2011, p. 251). Managers' use of "face-to-face channels is positively associated with employee satisfaction" (Men, 2014a, p. 264). Many scholars have recognised "the importance of employee-organisation relationships in achieving organisational success and have examined factors that contribute to positive employee relational outcomes" (Men 2015, p. 465), among which are also internal communication channels, such as face-to-face 
communication and social media platforms (e.g., Men 2014a; 2014b; 2015). In the analysis "based on a sample of 545 employees at different positions in medium and largesized corporations in the United States," Men (2015, p. 468) found out that "managers most frequently use emails and face-to-face channels to communicate with employees". The presence of managers on social media positively and strongly correlates with employee relational outcomes. Employees are more satisfied in the organizations, where managers use interpersonal communication, and less computer-mediated communication, such as email. Interpersonal communication is based on non-verbal communication and allows immediate feedback, and at the same time indicates manager's willingness to listen to their employees. "Social media communication, which is relational, interactive, communal, and personal, mimics traditional face-to-face interpersonal communication" (Erjavec et al., 2018, p. 562). Erjavec et al. (2018) interviewed 205 employees from Slovenia and Serbia and found that "that top managers most commonly utilise face-to-face communication, while middle managers most frequently use emails and telephone calls, and frontline managers use face-to-face communication and telephone calls. Employees are more satisfied with the organisation when their managers use more telephone calls and emails to communicate with them" (p. 559). As no study has examined whether nurses are content with the communication channels used by nurse managers working at different management levels, the following question should be raised:

RQ3: How is the use of nurse managers' communication channels associated with the relationship between employees (employee trust, control mutuality, commitment, and satisfaction) and the organisation in Croatia and Slovenia?
The study also anticipates the nurses' satisfaction with the interpersonal communication channels, such as face-to-face communication, used by nurse managers, who influence the quality of employee-organisation relationships:

H3: Satisfaction with the nurse managers' utilisation of interpersonal communication channels is positively associated with all aspects of employee-organisation relationships: employee trust, control mutuality, commitment, and satisfaction.

\section{METHOD}

\subsection{Population and sample}

An online survey was conducted to explore the research questions. The study population comprised of nurses in primary, secondary and tertiary health organisations in Croatia and Slovenia. We include a range of health organisations to enrich the generalisability of data. To achieve a representative sample (age, income and education levels) we employed stratified and quota random sampling. The final sample size of 272 respondents was obtained (148 from Croatia and 124 from Slovenia). The final sample was composed of $15.4 \%$ males and $84.6 \%$ females, $43.0 \%$ working in primary, $39.0 \%$ in secondary, $12.9 \%$ in tertiary sector. The majority of respondents $(71.7 \%)$ were aged up to 30, and have worked in health care between 11 to 20 years $(73.5 \%)$. More than a half of them $(65.0 \%)$ finished secondary school. All respondents were able to select all analysed communication channels.

\subsection{Measures}

Manager's communication channels usage was measured by using three 5-point Likert-type scale (from $1=$ never to $5=$ very often). The following questions were 
asked: (a) "How often does your top nurse manager use (the name of the medium) to communicate with you?"; (b) "How often does your middle nurse manager use (the name of the medium) to communicate with you?"; (c) "How often does your executive nurse manager use (the name of the medium) to communicate with you?".

Satisfaction with the use of nurse managers' communication channels was measured by using the three 5-point Likert-type scale (from $1=$ completely dissatisfied to 5 = completely satisfied). The following questions were asked: (a) "To what extent are you satisfied with the use of (the name of the medium) for communicating with your top nurse manager?", (b) "To what extent are you satisfied with the use of (the name of the medium) for communicating with your middle nurse manager?" and (c) "To what extent are you satisfied with the use of (the name of the medium) for communicating with your executive nurse manager?".

Employee-organisational relations were measured in this study by using a sevenpoint Likert scale (ranging from 1 = strongly disagree to $7=$ strongly agree). The measure was adapted from the widely used measurement of organization-public relationships, developed by Hon and Grunig (1999). This instrument comprises the following four sub-constructs: employee trust (e.g., "This company can be relied on to keep its promises."), control mutuality (e.g., "This company and I are attentive to what each other says."), commitment (e.g., "I would rather work together with this company than not."), and satisfaction (e.g., "I enjoy dealing with this company.").

Although this study is a continuation of the existing line of research on managers' channels of communication, the pretest with 20 employees from three health organisations in Croatia and Slovenia in
December 2016 was conducted. They provided feedback on the wording, thematic clarity, and format of the survey. We also conducted analysis of the reliability and validity of the measures, which demonstrated good validity and reliability. Internal validity of the construct was good $(\alpha=0.81)$. In January 2017, 272 randomly selected employees from various health organisations received the final online questionnaire.

Data were analysed by SPSS 24.0, using descriptive and correlation statistics. Since the employee-organizational relations variable consists of four dimensions (employee trust, control mutuality, commitment, and satisfaction), a construct was formed.

\section{RESULTS}

\subsection{Use of communication channels by managers}

Respondents pointed out that their top nurse managers most commonly use emails $(M=3.14, \mathrm{SD}=0.78)$, public notices $(M$ $=3.12, \mathrm{SD}=0.82$ ), electronic texts (home page, intranet) $(M=3.10, \mathrm{SD}=0.84)$, and physical texts (reports, memos, company letters) $(M=3.10, S D=0.83)$ to communicate with employees. Face-to-face communication $(M=2.99$, $\mathrm{SD}=0.75)$, such as meetings, managers walking around, and phone calls $(M=2.93, \mathrm{SD}=0.74)$ followed. The respondents reported that their top nurse managers also use video calls, chats, blogs, internal social network sites (such as internal Facebook) and instant messaging.

Results show that middle nurse managers most commonly use face-to-face communication $(M=3.69, S D=0.99)$, phone calls $(M=3.48, \mathrm{SD}=0.93)$, emails $(M=$ $3.15, \mathrm{SD}=0.81)$, public notices $(M=3.12$, $\mathrm{SD}=0.86)$, and physical texts $(M=3.11$, 
$\mathrm{SD}=0.88)$. There were some reported communication channels (chats, blogs, internal social network sites, instant messaging, video calls) that were utilised less frequently.

Results also show that executive nurse managers usually use face-to-face communication $(M=3.70, \mathrm{SD}=0.96)$, phone calls $(M=3.40, \mathrm{SD}=0.90)$, emails $(M=3.17$, $\mathrm{SD}=0.76)$, public notices $(M=3.12, \mathrm{SD}=$ $0.86)$, physical texts $(M=3.01, \mathrm{SD}=0.73)$, and instant messaging $(M=3.0, \mathrm{SD}=61)$. There were some reported communication channels (chats, blogs, internal social network sites, and video calls) that were applied less frequently.

\subsection{Employees' satisfaction with communication channels utilised by managers}

Results show the respondents' highest level of content when top nurse managers use emails $(M=3.54, \mathrm{SD}=0.66)$, followed by public notices $(M=2.98, \mathrm{SD}=$ $0.70)$, physical texts $(M=2.81, \mathrm{SD}=0.74)$, face-to-face communication $(M=2.66, \mathrm{SD}$ $=0.76)$, and electronic texts $(M=2.59$, SD $=0.96)$. They are less satisfied with managers' use of internal social network sites $(M$ $=2.43, \mathrm{SD}=0.66)$, video calls $(M=2.18$, $\mathrm{SD}=0.86)$, chats $(M=2.17, \mathrm{SD}=0.77)$, blogs $(M=2.13, \mathrm{SD}=0.96)$, phone calls $(M=2.03, \mathrm{SD}=0.78)$ and instant messaging $(M=2.01, \mathrm{SD}=0.55)$.

Respondents reported that they are the most satisfied when middle nurse managers employ face-to-face communication $(M=3.98, \mathrm{SD}=0.76)$, communication by emails $(M=3.68, \mathrm{SD}=0.82)$ and phone calls $(M=3.42, \mathrm{SD}=0.86)$. They are less satisfied with managers' use of public notices $(M=2.95, \mathrm{SD}=0.98)$, electronic texts $(M=2.90, \mathrm{SD}=0.96)$, internal social network sites $(M=2.86, \mathrm{SD}=0.67)$, physical texts $(M=2.84, \mathrm{SD}=0.76)$, video calls $(M$ $=2.49, \mathrm{SD}=0.73), \operatorname{blogs}(M=2.44, \mathrm{SD}=$ $0.99)$, instant messaging $(M=2.44, \mathrm{SD}=$ $0.66)$, and chats $(M=2.31, \mathrm{SD}=0.91)$.

Respondents are most satisfied when executive nurse managers utilize face-toface communication $(M=3.70, \mathrm{SD}=0.72)$, emails $(M=3.69, \mathrm{SD}=0.59)$, phone calls $(M=3.59, \mathrm{SD}=0.62)$, instant messaging $(M=3.12, \mathrm{SD}=0.72)$, and internal social network sites $(M=3.12, \mathrm{SD}=0.82)$ to communicate with them. They are less satisfied with managers' use of physical texts $(M=2.99, \mathrm{SD}=0.78)$, electronic texts $(M=$ 2.81, $\mathrm{SD}=0.79)$, public notices $(M=2.76$, $\mathrm{SD}=0.83), \operatorname{blogs}(M=2.75, \mathrm{SD}=0.98)$, and chats $(M=2.53, \mathrm{SD}=0.88)$.

Table 2. Bivariate relationship between categorical variables and satisfaction with nurse managers' communication channels using ANOVA $(n=272)$

\begin{tabular}{|l|c|c|c|c|c|}
\hline & Country & Gender & Age & Level of education & Sector \\
\hline Top managers & & & & & \\
\hline Face-to-face & 1.97 & 8.03 & 13.64 & 3.86 & 11.95 \\
\hline Phone calls & 0.15 & 6.00 & 10.65 & 2.73 & 13.50 \\
\hline Emails & 0.17 & 4.26 & 15.10 & 6.95 & 5.31 \\
\hline Physical texts & 0.36 & 1.80 & 9.75 & 6.38 & 17.06 \\
\hline Electronic texts & 1.2 & 4.88 & $11.54^{*}$ & 5.44 & 14.22 \\
\hline Video calls, conferences & 0.33 & 7.22 & $14.67^{*}$ & 7.92 & 13.29 \\
\hline Chats & 0.28 & 5.98 & 9.89 & 4.22 & 8.39 \\
\hline
\end{tabular}


Journal of Contemporary Management Issues

\begin{tabular}{|l|c|c|c|c|c|}
\hline Blogs & 0.89 & 7.08 & 11.43 & 6.51 & 15.39 \\
\hline Instant messaging & 1.22 & 6.07 & $14.77^{*}$ & 5.86 & 16.39 \\
\hline $\begin{array}{l}\text { Internal social network } \\
\text { sites }\end{array}$ & 3.22 & 5.33 & $13.43^{*}$ & 4.96 & 14.79 \\
\hline Public notices & 0.01 & 3.09 & 7.57 & 7.44 & 8.77 \\
\hline Middle managers & & & & & \\
\hline Face-to-face & 0.10 & 2.78 & 12.38 & 12.00 & 12.27 \\
\hline Phone calls & 0.21 & 4.15 & 13.46 & 9.58 & 9.30 \\
\hline Emails & 0.38 & 4.76 & 7.93 & 12.23 & 17.60 \\
\hline Physical texts & 0.06 & 3.74 & 11.76 & 8.33 & 10.30 \\
\hline Electronic texts & 0.41 & 5.78 & 12.44 & 6.49 & 13.42 \\
\hline Video calls, conferences & 2.33 & 6.12 & $13.77^{*}$ & 8.72 & 11.39 \\
\hline Chats & 0.03 & 4.88 & $12.79^{*}$ & 5.12 & 14.59 \\
\hline Blogs & 2.91 & 6.18 & $10.53^{*}$ & 6.71 & 11.89 \\
\hline Instant messaging & 1.82 & 6.01 & $13.87^{*}$ & 7.77 & 14.99 \\
\hline $\begin{array}{l}\text { Internal social network } \\
\text { sites }\end{array}$ & 0.01 & 4.23 & $12.53^{*}$ & 3.71 & 11.59 \\
\hline Public notices & 0.06 & 12.49 & 13.66 & 4.31 & 12.74 \\
\hline Executive managers & & & & & 13 \\
\hline Face-to-face & 0.41 & 8.06 & 13.64 & 3.86 & 11.95 \\
\hline Phone calls & 0.01 & 6.02 & 10.67 & 2.73 & 13.50 \\
\hline Emails & 0.24 & 4.33 & 15.10 & 6.96 & 5.31 \\
\hline Physical texts & 0.23 & 1.89 & 9.75 & 6.38 & 13.06 \\
\hline Electronic texts & 0.55 & 3.79 & $12.84^{*}$ & 7.31 & 11.32 \\
\hline Video calls, conferences & 2.63 & 4.49 & $13.77^{*}$ & 2.22 & 12.19 \\
\hline Chats & 0.09 & 3.87 & $10.59^{*}$ & 5.12 & 7.39 \\
\hline Blogs & 2.11 & 6.11 & $12.53^{*}$ & 4.41 & 12.49 \\
\hline Instant messaging & 1.7 & 7.99 & $15.87^{* *}$ & 4.71 & 14.29 \\
\hline $\begin{array}{l}\text { Internal social network } \\
\text { sites }\end{array}$ & 0.01 & 4.23 & $12.53^{*}$ & 2.46 & 15.81 \\
\hline Public notices & 0.2 & 3.05 & 8.95 & 1.97 & 11.63 \\
\hline Notes: F-ang & & & & \\
\hline & & & & & \\
\hline
\end{tabular}

Notes: $\mathrm{F}$-value; ${ }^{* * *} \mathrm{p}<.001 ; * \mathrm{p} p<.01 ;{ }^{*} \mathrm{p}<.05$.

Bivariate analysis between categorical variables and nurses' satisfaction with the usage of nurse managers' communication channels (see Table 2) showed significant differences in satisfaction with the use of nurse managers' communication channels depending on age. Younger employees are significantly more satisfied with nurse managers' use of new communication and information technologies.

No significant difference was found in satisfaction with the use of nurse managers' communication channels in terms of country, gender, levels of education and 
sector. This means that respondents' satisfaction with the use of nurse managers' communication channels did not differ significantly between Slovenian and Croatian respondents, male and female respondents, respondents who finished secondary and higher education level, and respondents working in primary, secondary, and tertiary sector.

Table 3. Satisfaction with nurse managers' communication channels using ANOVA $(n=272)$

\begin{tabular}{|c|c|c|c|c|c|c|c|c|c|}
\hline Satisfaction & $\overline{\mathbf{x}}$ & SD & Satisfaction & $\overline{\mathbf{x}}$ & SD & Satisfaction & $\overline{\mathbf{x}}$ & SD & F-value \\
\hline $\begin{array}{c}\text { Top } \\
\text { managers }\end{array}$ & & & $\begin{array}{c}\text { Middle } \\
\text { managers }\end{array}$ & & & $\begin{array}{l}\text { Executive } \\
\text { managers }\end{array}$ & & & \\
\hline $\begin{array}{l}\text { 4. Face-to- } \\
\text { face }\end{array}$ & 2.66 & 0.76 & $\begin{array}{l}\text { 1. Face-to- } \\
\text { face }\end{array}$ & 3.98 & 0.76 & $\begin{array}{l}\text { 1. Face-to- } \\
\text { face }\end{array}$ & 3.70 & 0.99 & $8.79 *$ \\
\hline $\begin{array}{l}\text { 10. Phone } \\
\text { calls }\end{array}$ & 2.03 & 0.78 & $\begin{array}{l}\text { 3. Phone } \\
\text { calls }\end{array}$ & 3.42 & 0.86 & $\begin{array}{l}\text { 3. Phone } \\
\text { calls }\end{array}$ & 3.59 & 0.62 & $7.11^{*}$ \\
\hline 1. Emails & 3.54 & 0.66 & 2. Emails & 3.68 & 0.82 & 2. Emails & 3.69 & 0.59 & 8.64 \\
\hline $\begin{array}{l}\text { 3. Physical } \\
\text { texts }\end{array}$ & 2.81 & 0.74 & $\begin{array}{l}\text { 7. Physical } \\
\text { texts }\end{array}$ & 2.84 & 0.76 & $\begin{array}{l}\text { 6. Physical } \\
\text { texts }\end{array}$ & 2.99 & 0.78 & 7.12 \\
\hline $\begin{array}{l}\text { 5. Electronic } \\
\text { texts }\end{array}$ & 2.59 & 0.96 & $\begin{array}{l}\text { 5. Electronic } \\
\text { texts }\end{array}$ & 2.90 & 0.96 & $\begin{array}{l}\text { 7. Electronic } \\
\text { texts }\end{array}$ & 2.81 & 0.79 & \\
\hline $\begin{array}{l}\text { 7. Video } \\
\text { calls, } \\
\text { conferences }\end{array}$ & 2.18 & 0.86 & $\begin{array}{l}8 . \text { Video } \\
\text { calls, } \\
\text { conferences }\end{array}$ & 2.49 & 0.73 & $\begin{array}{l}\text { 11. Video } \\
\text { calls, } \\
\text { conferences }\end{array}$ & 2.45 & 0.78 & 7.15 \\
\hline 8. Chats & 2.17 & 0.77 & 11. Chats & 2.31 & 0.91 & 10. Chats & 2.53 & 0.88 & 8.35 \\
\hline 9. Blogs & 2.13 & 0.96 & 9. Blogs & 2.44 & 0.99 & 8. Blogs & 2.75 & 0.98 & 8.12 \\
\hline $\begin{array}{l}\text { 11. Instant } \\
\text { messaging }\end{array}$ & 2.01 & 0.55 & $\begin{array}{l}\text { 10. Instant } \\
\text { messaging }\end{array}$ & 2.44 & 0.66 & $\begin{array}{l}\text { 4. Instant } \\
\text { messaging }\end{array}$ & 3.12 & 0.72 & $8.49^{*}$ \\
\hline $\begin{array}{l}\text { 6. Internal } \\
\text { social } \\
\text { network sites }\end{array}$ & 2.43 & 0.66 & $\begin{array}{l}6 . \text { Internal } \\
\text { social } \\
\text { network } \\
\text { sites }\end{array}$ & 2.86 & 0.67 & $\begin{array}{l}\text { 5. Internal } \\
\text { social } \\
\text { network } \\
\text { sites }\end{array}$ & 3.12 & 0.82 & $7.96^{*}$ \\
\hline $\begin{array}{l}\text { 2. Public } \\
\text { notices }\end{array}$ & 2.98 & 0.70 & $\begin{array}{l}\text { 4. Public } \\
\text { notices }\end{array}$ & 2.95 & 0.97 & $\begin{array}{l}\text { 9. Public } \\
\text { notices }\end{array}$ & 2.76 & 0.83 & 7.99 \\
\hline
\end{tabular}

*The mean difference is significant at the 0.05 level.

Results show (see Table 3) that there are differences in the employees' satisfaction with the use of communication channels by nurse managers who are working at different levels. Respondents reported they were most satisfied with the application of faceto-face communication by middle managers $(M=3.98, \mathrm{SD}=0.76)$ then by executive managers $(M=3.70, \mathrm{SD}=0.99)$, and were less satisfied with top managers $(M=2.66$, $\mathrm{SD}=0.76)$. Respondents were satisfied when executive managers $(M=3.59, \mathrm{SD}=$ $0.62)$ and middle managers $(M=3.42, \mathrm{SD}=$ 0.86 ) communicate by phone, but not when top managers use this mean of communication $(M=2.03, \mathrm{SD}=0.78)$. Employees 
were satisfied when executive managers were using instant messaging $(M=3.12$, $\mathrm{SD}=0.72)$, but the same does not apply to middle managers $(M=2.44, \mathrm{SD}=0.66)$, and, especially, top managers who used instant messaging to communicate with them $(\mathrm{M}=2.01, \mathrm{SD}=0.55)$. Respondents were also most satisfied with the executive ( $M$ $=3.12, \mathrm{SD}=0.82)$, followed by middle managers $(M=2.86, \mathrm{SD}=0.67)$, and least satisfied with top managers' use of the internal social network, such as Facebook $(M=2.43, \mathrm{SD}=0.66)$. No significant differences in satisfaction with the use of nurse managers' communication channels at different management levels considering emails, physical texts, video calls, conferences, chats, blogs and public notices were identified. Employees were most satisfied with managers' communication at all levels, when sending emails.

\subsection{Satisfaction with the nurse managers' application of communication channels and employee-organization relationships}

Correlations between satisfaction with the executive nurse managers' use of communication channels and construct of employee-organization relationships (employee trust, control mutuality, commitment, and satisfaction) reveals that employees' satisfaction with executive managers' utilization of face-to-face communication $(r=0.56, p<0.01)$ and emails $(r=0.64, p$ $<0.01)$ positively and moderately correlates with employee relational outcomes. Correlations between satisfaction with the middle and top nurse managers' use of communication channels and employeeorganization relationships show that employees' satisfaction with middle managers' $(r=0.86, p<0.01)$ and top managers' $(r=$ $0.70, p<.01)$ use of emails positively and strongly correlates with employee-organization relationships. Yet, the other correlations were not significant.

\section{DISCUSSION AND CONCLUSION}

This study explored the nurses' satisfaction with the communication channels, used by nurse managers at different management levels in Croatia and Slovenia and the correlation of satisfaction with the communication channels, used by nurse managers and employee-organisation relationships. The results provide additional insights into current literature on managers' and employees' communication.

\subsection{Use of communication channels by managers}

The results concerning communication channels show that managers at different levels use different communication channels in communicating with employees. Therefore, it is important to measure the usage of communication channels by managers at different management levels.

Top managers most commonly use mediated communication channels, emails, electronic texts, public notices and physical texts, middle and executive nurse managers use more interpersonal channels, followed by communication via emails, public notices and physical texts; executive nurse managers also use instant messaging. These findings confirm the results of other studies on managers' use of communication channels (Crescenzo, 2011; Men, 2014a, 2014b; Men and Hung-Baesecke, 2015), showing that organizations use both interpersonal and mediated communication in communicating with employees. The fact that the lower management uses more interpersonal communication channels 
could be explained by the fact that middle and executive managers, who intensively work with employees and other stakeholders (in our case patients), choose interpersonal approach to communicate with them due to a high need for feedback (Holmin and Safarova, 2015). These results are not in concordance with those of Erjavec et al. (2018) discovering that top managers in Slovenian and Serbian companies usually use face-to-face communication. This could be explained by the fact that the majority of Slovenian top nurse managers lack business and communication knowledge and, due to being overworked, mainly use mediated communication which gives them more control over time and takes less time (Erjavec and Starc, 2017).

By looking into internal social network sites, the results show that social network sites have not been commonly used by nurse managers at any management levels. Studies based on communication channels, used by managers of companies (Crescenzo, 2011; Men, 2014a, 2014b; Men and Hung-Baesecke, 2015; Erjavec et al., 2018) show that managers use internal social networking sites more frequently. This difference exists because nurse managers in Croatia and Slovenia probably still consider internal social networking sites as new communication tools, and they lack knowledge in employing them, while communicating with their employees. This difference may also be explained by the fact that health organisations in Croatia and Slovenia are relatively low technologically equipped with communication technology, and managers, consequently, do not use social networking sites in communication with employees (Kern, 2005; Meglič et al., 2007). However, the conservative use of internal social network sites between Slovenian and Serbian companies was also demonstrated in the study by Erjavec et al. (2018). This indicates that the majority of managers in this region are reluctant to use new technology in the organization.

\subsection{Employees' satisfaction with communication channels utilised by managers}

The results on the employees' satisfaction with communication channels used by managers show that they are most satisfied when top nurse managers use emails, middle nurse managers face-to-face communication, emails and phone calls, executive nurse managers face-to-face communication, emails, phone calls, instant messaging and internal social networks to communicate with them. In other words, employees prefer to use mediated communication channels (email) in comm unicating with top nurse managers, both interpersonal and mediated communication to communicate with middle nurse managers, and more interpersonal and non-formal communication than mediated communication to communicate with executive nurse managers. They also prefer to use internal social networking sites, such as Facebook, to communicate with executive nurse managers, which could be explained by the fact that communication on social networking sites is relational (Men, 2014a) and works as interpersonal communication, which respondents primarily prefer.

By looking into the use of communication channels with regards to management levels, the results show that a higher management level implies more formal and mediated communication between managers and employees. Thus, to communicate with their employees, top nurse managers should use emails, middle nurse managers face-toface communication, emails and phone calls, and executive nurse managers face-to-face communication, emails, phone calls, instant messaging and internal social network. 
The study also shows that younger employees are significantly more satisfied with nurse managers' use of new communication and information technologies, which is not surprising, since younger population in Croatia and Slovenia daily use new technology to communicate (Medijska potrošnja $\mathrm{V}$ Sloveniji, 2016). This means that, due to the generational changes of employees, managers at all management levels should soon start using new technology more actively in communicating with their employees.

\subsection{Satisfaction with the nurse managers' application of communication channels and employee-organization relationships}

The study also shows that satisfaction with interpersonal communication, used by the executive nurse managers, is positively associated with employee relational outcomes, while satisfaction with middle managers and top managers' utilization of emails is positively associated with employee-organization relationships. Thus, executive nurse managers should pay a special attention to ensure quality of face-to-face communication, while top and middle nurse managers quality of communication via email.

\subsection{Limitations and future research}

Despite the interesting results, the study also has certain limitations. As data were gathered only from the perspective of employees, a possible bias exists in the measurements. Future research should also include the managers' perspective. Since physicians, also, have a crucial role in the organisational power in health institutions (Krešić, 2013), future research should include their perspective, as well. Further studies could use qualitative approaches, using focus groups, observations or indepth interviews, to identify reasons why managers and their employees use specific communication channels and best practice, so as to provide specific guidelines for managers and employees.

\section{REFERENCES}

1. Baskin, O., Aronoff, C., Lattimore, D. (1997): Public Relations: The profession and the Practice. Chicago: Brown and Benclunark.

2. Bharadwaj, A. (2014): Planning internal communication profile for organizational effectiveness. IIM Kozhikode Society \& Management Review, 3 (2), 183-192.

3. Byrne, Z.S., LeMay, E. (2006): Different media for organizational communication: Perceptions of quality and satisfaction. Journal of Business and Psychology, 21 (2), 149-173.

4. Crescenzo, S. (2011): Internal employee communications media, in The IABC Handbook of Organizational Communication. Ed. T. Gillis. San Francisco, CA: Jossey-Bass, 219-230.

5. Daft, R. L., Lengel, R. H. (1984): Information richness: A new approach to managerial behavior and organization design. Texas: College of Business Administration.

6. Erjavec, K., Arsenijević, O., Starc, J. (2018): Satisfaction with managers' use of communication channels and its effect on employee-organisation relationships. JEEMS, 23 (4) 2018, 559 - 578.

7. Fernandes, M. C. , Sales da Silva, M., Magalhăes Moreira, T.M., Rocineide Ferreira da Silva, M. (2013): Factors involved in the management of nursing care. $O B J N, 12$ (2), 522-533.

8. Holá, J. (2012): The Importance of Internal Communication in Hospital 
Management. Profese 5 (1), 5-10.

9. Holmin, J., Safarova, J. (2015): Appropriateness of Internal Communication Channels: A Stakeholder Approach. Uppsala: Uppsala University.

10. Hon, L., Grunig, J. (1999). Guidelines for measuring relationships in public relations. http://www.instituteforpr.org/ index.php/IPR/research_single/guidelines_measuring_relationships/ (accessed in February 2019).

11. Kern, J. (2005): Zdravstvo digitalnog doba. Hrvatski časopis za javno zdravstvo, 1 (3), 30-34.

12. Kern, J. (2014): Information and communication technologies in nursing. Acta Medica Croatica, 68 (1), 3-5.

13. Kim, J.,Rhee, Y. (2011): Strategic thinking about employee communication behavior (ECB) in public relations: testing the models of megaphoning and scouting effects in Korea. Journal of Public Relations Research, 23 (2), 243-268.

14. Krešić, V. (2013): Komunikacija u sestrinstvu-međuljudski odnosi zdravstvenih djelatnika. Sestrinski glasnik, 18 (1), 41-43.

15. Kugović, N. (2013). Sindrom izgorevanja pri zaposlenih v nujni medicisnki pomoči. Obzor Zdrav Neg., 47 (3): 268-275.

16. Kwateng, K. O., Osei, H. V., EkowAbban, E. (2014): Organizational communication in Public Health Institutions. International Journal of Business and Management, 9 (11), 179-188.

17. Lega, F., Prenestini, A., Spurgeon, P. (2013): Is Management Essential to Improving the Performance and Sustainability of Health Care System and Organizations? A Systematic Review and a Roadmap for Future Studies. Value Health, 16 (1): 46-51.
18. Li-Min, L., Jen-Her, W., Ing-Ching, H., Kua-Hung, T. (2007): Management Development: A Study of Nurse Managerial Activities and Skills. Journal of Healthcare Management, 52 (3), 156-169.

19. Lorber M. (2015): Značilnosti in kompetence vodij $v$ povezavi $s$ počutjem zaposlenih $v$ zdravsteni negi [dissertation]. Maribor: University of Maribor: Ekonomsko-poslovna fakulteta.

20. Martinez, J. M. (2015): Nursing Leadership \& Management. https://www. slideshare.net/jofred/nursing-leadership-management-54826140 (accessed in November 2019).

21. Matić, I., Kern, J., Svetić Čišić, R., Matić, N. (2014): Virtualna komunikacija u sestrinstvu-jesmo li spremni?, Acta Medica Croatica, 68 (1), 7-13.

22. McLuhan, M. (1964): The Extension of Man. Boston: MIT Press.

23. Medijska potrošnja v Sloveniji (2016). https://iprom.si/iprom-in-valicon-znovo-raziskavo-o-medijski-potrosnjitelevizija-aktivno-spodbuja-uporabointerneta/ (accessed in January 2016).

24. Meglič, M., Marušič, D., Anžur, A., Kodele, D. (2007): Opremeljenost in uporaba informacijskih tehnologij $\mathrm{V}$ bolnišnicah in zdravstvenih domovih $\mathrm{v}$ Sloveniji. Informatica Medica Slovenica, 12 (2), 34-39.

25. Men, L. R. (2014a): Strategic employee communication: transformational leadership, communication channels, and employee satisfaction. Management Communication Quarterly, 28 (2), 264-284.

26. Men, L. R. (2014b): Why leadership matters to internal communication: linking transformational leadership, symmetrical communication, and employee outcomes. Journal of Public Relations Research, 26, (3), 256-279. 
27. Men, L. R. (2015): The internal communication role of the chief executive officer: Communication channels, style, and effectiveness, Public Relation Review, 41 (4), 461-471.

28. Men, L. R., Hung-Baesecke, C. F. (2015): Engaging employees in China: The impact of communication channels, organizational transparency, and authenticity. Corporate Communications: An International Journal, 16 (4), 328-346.

29. Meyrowitz, J. (1998): Multiple media literacies. Journal of Communication, 48 (1), 96-108.

30. Prosser, B., Olson, R. (2013): Changes in Conceptual human care work. Health Sociology Review, 22 (4), 422-432.

31. Rigolosi, E. (2013): Management and Leadership in Nursing and Health Care. New York: Springer Publishing Company.
32. Rogers, R. (2012): Leadership communication styles: descriptive analysis of health care professionals. Journal of Healthcare Leadership, 4 (1), 47-57.

33. Starc, J., Erjavec, K. (2017): Competencies of nurse managers in Slovenia: A qualitative and quantitative study. Central European Journal of Nursing and Midwifery, 5 (3): 383-390.

34. Welch, M. (2012): Appropriateness and acceptability: Employee perspectives of internal communication. Public Relations Review, 38 (2), 246-254.

35. White, C., Vanc, A., Stafford, G. (2010): Internal communication, information satisfaction, and sense of community: The effect of personal influence. Journal of Public Relations Research, 22 (1), 65-84.

36. Zavrl Džananović, D. (2010): Patronažno varstvo Slovenije včeraj, danes, jutri. Obzornik zdravstvene nege, 44 (2), 117-125.

\section{ZADOVOLJSTVO MEDICINSKIH SESTARA KORIŠTENJEM KOMUNIKACIJSKIH KANALA OD STRANE MENADŽERA U HRVATSKOJ I SLOVENIJI}

Sažetak. Prethodna su istraživanja zanemarivala zadovoljstvo medicinskih sestara korištenjem komunikacijskih kanala od strane njihovih menadžera. U ovom se radu želi utvrditi koliko su medicinske sestre u Hrvatskoj i Sloveniji zadovoljne s uporabom komunikacijskih kanala od strane svojih menadžera te koliko je zadovoljstvo povezano s odnosom između zaposlenika $i$ organizacije. U okviru istraživanja, prikupljeni su podaci od 272 medicinske sestre u Hrvatskoj i Sloveniji, koristeći elektronički upitnik, koji su ispitanici(e) samostalno ispunjavali. Rezultati ukazuju da menadžeri medicinskih sestara na najvišoj razini uglavnom koriste indirektne komunikacijske kanale, dok se na srednjoj i nižoj razini organizacije uglavnom koriste osobni oblici komunikacije. Zaposlenici su najzadovoljniji kada menadžeri medicinskih sestara na najvišoj organizacijskoj razini koriste elektroničku poštu, dok je za srednju organizacijsku razinu zadovoljstvo najveće komunikacijom putem neposrednog kontakta, elektroničke pošte i telefona. Na najnižoj razini organizacije, zadovoljstvo je najveće, kada se komunicira neposrednim kontaktom, elektroničkom poštom, telefonom, elektroničkim porukama i internim društvenim mrežama. Mlađi su zaposlenici značajno zadovoljniji korištenjem novih komunikacijskih i informacijskih tehnologija. Istraživanje, također, pokazuje pozitivnu povezanost zadovoljstva neposrednom komunikacijom na najnižoj razini menadžmenta s odnosima između zaposlenika i organizacije. Nadalje, navedena se veza ostvaruje i na srednjoj te najvišoj razini menadžmenta, uz korištenje elektroničke pošte kao komunikacijskog sredstva.

Ključne riječi: upravljanje komunikacijom, komunikacijski kanali, odnosi između zaposlenika i organizacije. 